NBER WORKING PAPER SERIES

\title{
CAPITAL CONTROLS, LIBERALIZATIONS, AND FOREIGN DIRECT INVESTMENT
}

\author{
Mihir A. Desai \\ C. Fritz Foley \\ James R. Hines Jr. \\ Working Paper 10337 \\ http://www.nber.org/papers/w10337
NATIONAL BUREAU OF ECONOMIC RESEARCH 1050 Massachusetts Avenue
Cambridge, MA 02138
March 2004

The statistical analysis of firm-level data on U.S. multinational companies was conducted at the International Investment Division, Bureau of Economic Analysis, U.S. Department of Commerce under arrangements that maintain legal confidentiality requirements. The views expressed are those of the authors and do not reflect official positions of the U.S. Department of Commerce. The authors thank Kristen Forbes, Gita Gopinath, Nandini Gupta, Joe Kogan, Robert Lawrence, William Zeile and various seminar and conference participants for helpful comments on an earlier draft, and the Lois and Bruce Zenkel Research Fund at the University of Michigan and the Division of Research at Harvard Business School for financial support. The views expressed herein are those of the authors and not necessarily those of the National Bureau of Economic Research.

(C2004 by Mihir A. Desai, C. Fritz Foley, and James R. Hines Jr. All rights reserved. Short sections of text, not to exceed two paragraphs, may be quoted without explicit permission provided that full credit, including (C) notice, is given to the source. 
Capital Controls, Liberalizations, and Foreign Direct Investment

Mihir A. Desai, C. Fritz Foley, and James R. Hines Jr.

NBER Working Paper No. 10337

March 2004

JEL No. F21, F23, G15, H87, G18, G38

\section{ABSTRACT}

Affiliate-level evidence indicates that American multinational firms circumvent capital controls by adjusting their reported intrafirm trade, affiliate profitability, and dividend repatriations. As a result, the reported profit impact of local capital controls is comparable to the effect of 24 percent higher corporate tax rates, and affiliates located in countries imposing capital controls are 9.8 percent more likely than other affiliates to remit dividends to parent companies. Multinational affiliates located in countries with capital controls face 5.4 percent higher interest rates on local borrowing than do affiliates of the same parent borrowing locally in countries without capital controls. Together, the costliness of avoidance and higher interest rates raise the cost of capital, significantly reducing the level of foreign direct investment. American affiliates are 13-16 percent smaller in countries with capital controls than they are in comparable countries without capital controls. These effects are reversed when countries liberalize their capital account restrictions.

Mihir A. Desai

Harvard Business School

Morgan 363

Soldiers Field

Boston, MA 02163

and NBER

mdesai@hbs.edu

C. Fritz Foley

University of Michigan

Business School

701 Tappan Street

Ann Arbor, MI 48109-1234

ffoley@umich.edu
James R. Hines Jr.

University of Michigan

Business School

701 Tappan Street

Ann Arbor, MI 48109-1234

and NBER

jrhines@umich.edu 


\section{Introduction}

Countries that fear the economic disruptions that may accompany capital flows are often tempted to impose controls on international capital movements. These controls can take many forms, and their efficacy in promoting or deterring growth is hotly debated. The same countries are also typically eager to attract foreign direct investment due to the presumed salutary effects of such investment. The potential inconsistency of the desire to control capital movements and the desire to attract inbound foreign direct investment has heretofore received limited attention, in spite of its obvious policy relevance.

This paper offers evidence of the effects of capital controls on foreign direct investment, in the process addressing several related questions: What is the effect of capital controls on the cost of capital for foreign investors? Do multinational firms employ their internal product and capital markets to circumvent capital controls, and how do such efforts compare to actions triggered by income taxes? Are the effects of capital controls reversed when countries liberalize their capital account restrictions? And how much foreign direct investment does a country lose by imposing capital controls?

The results indicate that local borrowing rates are considerably higher in countries imposing capital controls; that multinational firms distort reported trade patterns, profitability, and dividend repatriations in order to mitigate the impact of capital controls; and that the costs that must be incurred in order to avoid capital controls together with higher interest rates significantly reduce levels of foreign direct investment. Borrowing rates are 5.4 percentage points higher in countries imposing capital controls than they are elsewhere for affiliates of the same multinational parents. The distortions to reported profitability are comparable to those incurred in response to 24 percent differences in corporate tax rates, and dividend repatriations are regularized to facilitate the extraction of profits from countries imposing capital controls. The avoidance of capital controls and high interest rates impose costs on foreign affiliates and therefore reduce the volume of investment by American firms. The initial capitalization of affiliates in countries with capital controls is 13-16 percent smaller than affiliates elsewhere and this smaller initial size is not offset by greater growth through increased profit retentions. These patterns are reversed when capital controls are removed. 
These results emerge from an analysis of how foreign affiliates of U.S. multinational firms respond to capital controls and their removal. The use of confidential affiliate-level data makes it possible to distinguish the behavior of foreign affiliates of the same parent companies operating in markets with and without capital controls. As a result, it is possible to obtain estimates of the impact of capital controls, while implicitly controlling for considerations that are common to all affiliates of the same company. The sample, which varies depending on the analysis, covers the activities of all U.S. multinational firms from 1982 to 1997.

Any analysis of firm-level responses to capital controls is complicated by two important considerations: capital controls are not randomly distributed among nations, and available indexes measure capital controls imprecisely. This paper attempts to overcome these difficulties by focusing on subtle predictions regarding firm behavior and by employing a measure tailored to capture the aspects of capital controls relevant for multinational firms. Although it is possible to control for observable country characteristics and firm fixed effects, the measured effect of capital controls on foreign investment may reflect the impact of omitted variables that affect investment and are correlated with the desire to control capital flows. Since there is a shortage of available instruments for the imposition or removal of capital controls, it is useful to look beyond predictions of the effects of controls on levels of foreign direct investment and to consider subtler predictions regarding the avoidance behavior of American firms. Consistent with these predictions, the evidence indicates that foreign affiliates in countries that control remittances are significantly more likely than other affiliates to smooth dividend repatriations, in spite of the associated tax and resource-allocation costs. The same affiliates have 4.7 percent lower reported profit rates than do comparable affiliates in countries without capital controls, and exhibit intrafirm trade patterns that shift profits away from host countries restricting capital flows, this behavior characteristic of affiliates located in countries with high tax rates. While it is impossible to rule out the confounding effects of the non-random assignment of capital controls, the tests suggest that the overall results do not merely reflect the conditions that give rise to the desire to impose capital controls.

Studies of capital controls and capital account liberalizations are also commonly hampered by the imprecise measurement of capital controls. As noted in Edison et al. (2003), measures employed in empirical work on capital controls typically are blunt. In order to address 
this problem, the empirical work in this paper employs a measure of capital account restrictions that is specifically associated with the activities of multinational firms, comparing the results to those obtained using a widely-adopted measure of capital account restrictions developed by the International Monetary Fund. This analysis of firm responses to capital account restrictions offers the advantage of being closely tied to the restrictions that firms actually face. As it happens, results obtained using the two control measures are consistent, though stronger when using the measure of capital controls tailored for situations facing multinational firms.

Section 2 of the paper reviews the empirical literature on the impact of capital account restrictions and liberalizations and ties the paper's results to the open questions in the literature. Section 3 offers an overview of the available data and describes aggregate patterns of multinational activity and capital account regulations. Section 4 presents empirical evidence of the effects of capital account restrictions on local interest rates, profit extraction, and investment levels. Section 5 is the conclusion.

\section{Capital Controls, Liberalizations and Economic Growth}

This section reviews the sizable macroeconomic and finance literature analyzing the effect of capital account restrictions on aggregate investment and the growing literature on the distributional consequences of capital account restrictions. Evidence of the effects of capital account restrictions on the behavior of multinational firms is complementary to these research streams. This section also examines the likely effects of capital controls on multinationals firms.

\subsection{Investment responses to capital controls and liberalizations}

Eichengreen (2002) provides an overview of the large literature on the aggregate effects of capital account liberalizations, concluding with the observation that liberalization "remains one of the most controversial and least understood policies of our day.” While few definitive conclusions have emerged, two important viewpoints can be distinguished. The skeptical view of capital account liberalization is most often associated with Rodrik (1998) and related work. Using the IMF classification of capital controls, Rodrik finds no significant statistical association between capital account openness and growth. This evidence is used to bolster a more general skepticism regarding the virtues of financial openness in the world of the second-best, as in 
Bhagwati (1998). The more optimistic view of capital account liberalization is advanced by Fischer (1998), and supported by evidence provided in Quinn (1997). Using an index subsequently adopted by many authors, Quinn reports a significant positive correlation between changes in his measure of capital account openness and subsequent economic growth.

The salience of these issues for policy makers has motivated work attempting to disentangle the reasons for these contradictory findings. In particular, researchers have focused on the distinctive nature of the IMF and Quinn measures (as in Edwards (2001)), the possibility that capital liberalization operates differently for countries of different income levels (as in Alesina, Grilli and Milesi-Ferretti (1994), which can be compared to Grilli and Millesi-Ferreti (1995)), the role of preexisting policies and the role of sequencing in determining the effects of capital control liberalizations (as in Arteta, Eichengreen and Wyplosz (2001) and Chinn and Ito (2002)), and the role of political institutions in dictating outcomes associated with capital account liberalizations (as in Quinn, Inclan and Toyoda (2001)). The effect of capital account liberalizations in stimulating economic growth and investment remains an open question.

Finance scholars have emphasized the effects of stock market liberalizations on investment using firm-level data. Following the intuition of Stulz (1995, 1999), Henry (2000), Bekeart and Harvey (2000), and Bekaert, Harvey and Lundblad (2002) find that stock market liberalizations in a set of emerging market countries are followed by investment booms by local firms listed on equity markets. Chari and Henry (2002) confirm the existence of investment booms, but find no evidence that the distribution of investment subsequent to a liberalization follows the predictions associated with the repricing of systematic risk. As such, investment booms may be more associated with reductions in the risk-free interest rate than with repricing of equity risk. Multinational responses to capital controls and liberalizations can shed light on the mechanisms underlying this investment boom by analyzing their investment behavior directly and by considering the extent to which borrowing costs are associated with capital controls.

\subsection{The distributional consequences of capital controls}

In addition to the aggregate effects described above, it is possible that capital controls distort the composition of investment and firm activity. Morck, Strangeland and Yeung (1998) and Rajan and Zingales (2003) both characterize capital controls as one example of a financial 
regulation that can have important distributional consequences across firms within the same country. Specifically, they argue that capital controls can favor entrenched firms and that these firms then lobby for their preservation. Johnson and Mitton (2003) demonstrate the nature of these distributional consequences by examining how political connections are linked to firm performance under capital controls in the case of Malaysia.

The distributional consequences of capital account policies need not arise from political connections alone. Forbes (2003) shows how smaller firms suffered during the Chilean encaje, suggesting that the consequences of these regulations may be quite heterogeneous across firms due to access to capital markets. Similarly, Auguste et al. (2003) consider the use of ADRs to facilitate capital flight during a period of capital controls, indicating that the impact of capital controls may depend on differential access to avoidance tactics.

Access to internal capital markets facilitates the evasion of capital controls by multinational firms. Desai, Foley, and Hines (2003) document the extent to which internal capital markets permit multinationals firms to substitute parent-provided debt for local borrowing in countries with underdeveloped capital markets. Similarly, Desai, Foley, and Forbes (2003) show that multinationals outperform local firms during severe currency crises by accessing internal capital markets as they pursue investment opportunities created by depreciations. ${ }^{1}$ Since multinationals may circumvent capital controls through the use of their internal markets and these internal markets are not available to all firms, capital controls could have significant distributional consequences. Given the overall importance of foreign direct investment to economic growth, as suggested by the findings of Aitken and Harrison (1999), understanding the effect of capital controls on the behavior of multinational firms is valuable in assessing the economic impact of capital account policies.

\subsection{Capital controls, capital costs and FDI}

The influence of capital controls - and their liberalization - on foreign direct investment depends on how controls influence the cost of capital for multinational firms. Capital controls are commonly thought to increase the cost of local borrowing, as in Dooley and Isard (1980),

\footnotetext{
${ }^{1}$ In a similar vein, Johnson, Boone, Breach and Friedman (2000) and Mitton (2002) suggest how cross-country and cross-firm variation in responses to corporate governance is associated with differential responses to currency crises.
} 
given that these controls, or the expectation of their imposition, prevent international capital flows from equalizing interest rates. Since a considerable fraction of the funding for local affiliates of multinational investors typically comes from local loans, higher interest rates increase the cost of capital and should be expected to discourage investment. By comparing the borrowing costs of affiliates of the same parent in countries with and without capital controls, it is possible to identify the degree to which interest rates respond to capital controls in a manner that is not confounded by differences in credit quality or other firm characteristics.

In addition to these differences in interest costs, profit repatriation restrictions that accompany capital controls can reduce effective returns to foreign investment by preventing multinational investors from repatriating their profits to the extent that they would do so in the absence of restrictions. It is useful to consider a simple formalization of this point. For firms investing in countries with capital controls the value of an investment can be expressed as $V(K)$, in which $K$ is the stock of capital held by the affiliate. Higher interest rates in countries with capital controls generally imply that $V(K)$ is less than the value of a comparable investment in a country without capital controls, but that is not the only impact of capital controls as controls also constrain the repatriation behavior of such affiliates. Following a period in which an affiliate earns profits of $\pi$, and putting tax considerations aside for simplicity, the affiliate has the choice of reinvesting its profits, remitting them as dividends, or using financial or other means to relocate the profits to other affiliates or the parent company in non-dividend form, possibly by adjusting the prices at which intercompany transactions are booked.

In the absence of capital controls, dividend repatriation policies would be governed by tax considerations and the need to use dividends to control cash flows and incentives within multinational firms. ${ }^{2}$ Let $d^{*}$ denote the firm's desired level of dividend remittance, and $d$ represent dividends actually paid; the affiliate is assumed to incur a cost equal to $\alpha\left(d-d^{*}\right)^{2}$, with $\alpha>0$, reflecting tax and organizational costs from imperfectly tailored dividend policies. The effect of capital controls on dividend levels is to impose that dividends satisfy $d \leq \bar{d}$, in which $\bar{d}$ is the affiliate's maximum permitted repatriation. Firms also have the ability to use various devices to relocate profits outside of affiliates in countries with capital controls, though 
these devices are likewise costly. Let $\delta$ denote the volume of profits earned by the affiliate in a capital control country but reported to be earned outside; the associated cost is given by $\mu \delta^{2}$, with $\mu>0$.

The problem facing the multinational affiliate with previous period capitalization of $K_{-1}$ is then to choose $d$ and $\delta$ to maximize:

$$
\begin{aligned}
& \max _{d, \delta}[V(K)+d+\delta] \\
& \text { s.t.: } K=K_{-1}+\pi-\left[d+\alpha\left(d-d^{*}\right)^{2}\right]-\delta(1+\mu \delta) \\
& d \leq \bar{d}
\end{aligned}
$$

The first order conditions corresponding to this maximization are:

$$
\begin{aligned}
V^{\prime}(K) & =\frac{1}{1+\mu \delta} \\
V^{\prime}(K) & =\frac{1-\lambda}{1+\alpha\left(d-d^{*}\right)},
\end{aligned}
$$

in which $\lambda$ is the shadow value associated with the constraint that $d \leq \bar{d}$.

Important features of the multinational firm's reactions to capital controls are evident from examination of conditions (2) and (3). If the repatriation restriction does not bind, then $\lambda=0, d=d^{*}$, and $\delta=0$, so $V^{\prime}(K)=1$, and all of the effects of capital controls on discouraging local investment come from the associated higher interest rates. In the more realistic case that repatriation restrictions bind, then $\lambda>0, d=\bar{d}$, and $V^{\prime}(K)=(1-\lambda) /\left[1+\alpha\left(\bar{d}-d^{*}\right)\right]<1$, so $\delta>0$. When repatriations restrictions bind, dividend remittances are insensitive to changes in desired dividends, and investors relocate some of their profits to other jurisdictions.

\footnotetext{
${ }^{2}$ For a discussion of the tax and agency motivations for dividend repatriation policies, see Desai, Foley and Hines (2001, 2002).
} 
Costs associated with higher local interest rates and regulatory impediments to profit repatriations reduce the desirability of investing in countries with capital controls, thereby reducing the value of $V(K)$ at any given level of $K$. Firms initially capitalize affiliates to the point that $V^{\prime}(K)=1$, but given the costs associated with capital controls, the level of $K$ at which $V^{\prime}(K)=1$ is smaller if a country has capital controls. The fact that $V^{\prime}(K)<1$ for affiliates facing binding repatriation restrictions implies that such affiliates might grow quickly, since a fraction of profits is effectively trapped. It does not follow that these affiliates will grow more quickly than others located in countries without capital controls, since firms can moderate growth rates with dividend repatriations and profit reallocations, and have incentives to do so given the costliness of operations in countries with capital controls. Hence, in order to measure the net impact of capital controls it is necessary to consider their impact on initial sizes of affiliates as well as patterns of retained earnings.

Finally, it is also possible that capital controls actually increase expected returns for multinational firms. Specifically, Aizenman (2002) examines the conditions under which macroeconomic volatility can discourage types of foreign direct investment. Given that one of the rationales for capital controls is reduced volatility, it is possible that multinationals respond to capital controls with increased investment. Consequently, the degree to which increased costs associated with higher interest rates, repatriation restrictions, and costly evasion technologies are offset by reduced volatility remains an open empirical question. The analysis that follows proceeds by directly examining borrowing costs, avoidance behavior, and affiliate sizes in order to assess the impact of capital controls on foreign direct investment.

\section{Data and Descriptive Statistics ${ }^{3}$}

The empirical work presented in section 4 is based on the most comprehensive available data on the activities of American multinational firms. The Bureau of Economic Analysis (BEA) annual survey of U.S. Direct Investment Abroad from 1982 through 1997 provides a panel of data on the financial and operating characteristics of U.S. firms operating abroad. These surveys ask reporters to file detailed financial and operating items for each affiliate and information on the value of transactions between U.S. parents and their foreign affiliates. The International 
Investment and Trade in Services Survey Act governs the collection of the data and the Act ensures that "use of an individual company's data for tax, investigative, or regulatory purposes is prohibited.” Willful noncompliance with the Act can result in penalties of up to $\$ 10,000$ or a prison term of one year. As a result of these assurances and penalties, BEA believes that coverage is close to complete and levels of accuracy are high.

U.S. direct investment abroad is defined as the direct or indirect ownership or control by a single U.S. legal entity of at least ten percent of the voting securities of an incorporated foreign business enterprise or the equivalent interest in an unincorporated foreign business enterprise. A U.S. multinational entity is the combination of a single U.S. legal entity that has made the direct investment, called the U.S. parent, and at least one foreign business enterprise, called the foreign affiliate. In order to be considered as a legitimate foreign affiliate, the foreign business enterprise should be paying foreign income taxes, have a substantial physical presence abroad, have separate financial records, and should take title to the goods it sells and receive revenue from the sale. In order to determine ownership stakes in the presence of indirect ownership, BEA determines the percentage of parent ownership at each link and then multiplies these percentages to compute the parent's total effective ownership.

The foreign affiliate survey forms that U.S. multinational enterprises are required to complete vary depending on the year, the size of the affiliate, and the U.S. parent's percentage of ownership of an affiliate. The most extensive data for the period examined in this study are available for 1982, 1989, and 1994, when BEA conducted Benchmark Surveys. In these years, all affiliates with sales, assets, or net income in excess of \$3 million in absolute value and their parents were required to file extensive reports. In non-benchmark years between 1982 and 1995, exemption levels were higher and less information was collected. ${ }^{4}$ Although majority owned affiliates report many accounting items and information concerning operations each year,

\footnotetext{
3 This description of the data is drawn from Desai, Foley and Hines (2002).

${ }^{4}$ From 1983-1988, all affiliates with an absolute value of sales, assets, or net income less than \$10 million were exempt from reporting requirements, and this cutoff increased to \$15 million from 1990-1993 and \$20 million in 1995. BEA uses reported data to estimate universe totals when surveys cover only larger affiliates or when only certain affiliates provide information on particular survey forms. Estimated data is unlikely to have a significant impact on the BEA's published data at the industry or country level as data based on actual reports exceeds 90 percent of the estimated totals of assets and sales in each of the years between 1982 and 1995 . To avoid working with estimated data, only affiliates required to provide all the information associated with a particular analysis are considered.
} 
minority owned affiliates must only file information about sales, net income, assets, employment, employment compensation, and trade with the United States in non-benchmark years. Majority owned affiliates are foreign affiliates in which the combined direct and indirect ownership of U.S. persons exceeds 50 percent. BEA collects identifiers linking affiliates through time, thereby permitting the creation of a panel.

Table 1 displays basic information on the incidence and size of affiliates in the three benchmark years - 1982, 1989, and 1994. In the most recent benchmark year, 20,898 entities are covered, with median sales and assets of approximately \$14 million. The bottom panel of Table 1 provides descriptive statistics for the variables employed in the statistical analysis presented in section 4. The parent trade surplus is the ratio of the parent company trade surplus (exports minus imports) with its foreign affiliate to total trade (exports plus imports). Net income is aftertax income reported in U.S. dollars, and the return on assets is the ratio of net income to the book value (in U.S. dollars) of gross assets. Tax rates are calculated from BEA data by taking the ratio of foreign income taxes paid to foreign pretax income for each affiliate, and using the medians of these rates as country-level observations for each country and year. ${ }^{5}$ Mean and median country tax rates are equal to approximately 34 percent over the sample period. Private Credit is the ratio of private credit lent by deposit money banks to GDP, as provided in Beck, Demirguc-Kunt, and Levine (2000). Political Risk is the average monthly assessment from the International Country Risk Guide, rescaled to lie between 0 and 1, with higher values indicating greater risk. ${ }^{6}$ Similarly, the Rate of Inflation is the contemporaneous percentage change in a host country’s GDP deflator.

The BEA data also contain information on the interest expense associated with affiliate debt, and it is possible to use this information to calculate an affiliate's average interest rate in a year. Because the data do not contain detailed information on interest rates charged on individual loans or on which types of debt are interest-bearing, the analysis uses two estimates of

\footnotetext{
${ }^{5}$ Affiliates with negative net income are excluded for the purposes of calculating country tax rates. For a more comprehensive description of the calculation of affiliate tax rates, see Desai, Foley and Hines (2001). In particular, these income tax rates do not include withholding taxes on cross-border interest payments to related parties, since such taxes are endogenous to interest payments and in any case immediately creditable against home-country tax liabilities. Desai and Hines (1999) report that adjusting country tax rates for withholding taxes does not affect the estimated impact of taxation on affiliate borrowing, due to the combination of creditability and low withholding tax rates on related-party interest payments.

${ }^{6}$ Since Political Risk data for 1982 are unavailable, 1984 values are used in their place.
} 
interest rates. The first measure is the Interest Rate on External Borrowing, which is calculated by dividing affiliate interest payments to non-parents by current liabilities and long-term debt borrowed from non-parent sources. This variable has a mean of 4.9 percent. One of the reasons that this average interest rate appears low is that the broad measure of debt used in this calculation includes trade credit which is often non-interest bearing. ${ }^{7}$ The second interest rate is the Interest Rate on Non-Trade Account Borrowing, which is the ratio of total interest paid to a measure of current liabilities and long term debt that excludes trade accounts and trade notes payable. This alternative interest rate variable has a mean of 7.9 percent. This variable includes interest payments to parents and external sources in the numerator and total debt in the denominator.

Table 2 provides detail on the two measures of capital account restrictions employed in the statistical analysis that follows. ${ }^{8}$ The IMF measure is the one most commonly used in the literature and, as documented in Table 2, is one that classifies many countries as having capital controls during the 1980s and 1990s. ${ }^{9}$ The IMF capital control classification is a yes-no measure, based on multiple aspects of a country's capital account restrictions, not all of them relevant to multinational firms. It is useful to consider an alternative to the IMF classification that emphasizes restrictions that are important to foreign investors; fortunately, Shatz (2000) provides one such measure. Shatz (2000) details measures of openness to FDI for a sample of 57 countries along a number of dimensions. ${ }^{10}$ Two of these are restrictions on capital repatriation and restrictions on profit remittance. Capital account restrictions obtained from these data are coded as a dummy variable equal to one if either of the restrictions is rated two or less, indicating policies that impose strict time or quantity limits on the ability of affiliates to move funds out of the host country.

\footnotetext{
${ }^{7}$ Interest rates are based on current interest payments and are recorded in U.S. dollars. The currency denomination of debt may be important to financial decision making within a multinational firm, but it is impossible to tell from the BEA data in which currency debt is formally denominated. See Kedia and Mazumdar (2003) and Allayannis, Brown and Klapper (2003) for analyses of the determinants of the currency denomination of debt.

${ }^{8}$ Table II is limited to countries for which the Shatz measure exists. Fortunately, these countries are the hosts to the vast majority of outbound U.S. foreign direct investment.

${ }^{9}$ The deficiencies in this measure, along with the revised measure, are considered in Eichengreen (2001).

${ }^{10}$ The IMF dummy covers the 1982-1995 period. Using the tables and text in Shatz (2000), it is possible to create the Shatz measure over the same time horizon. In order to increase the power of tests of the effects of liberalizations, we track the use of capital controls in countries that liberalize controls in the years between 1982 and 1995 through 1997 and use data over the 1982-1997 period.
} 
The comparison between the measures in Table 2 yields some interesting results. ${ }^{11}$ Any country that is considered free of capital controls by the IMF measure is likewise classified as free under the Shatz measure. However, numerous countries classified as restricted by the IMF are not considered restricted under the Shatz measure. In 1990, the correlation between the Shatz measure and the IMF measure was $0.30 .^{12}$

The middle panel of Table 1 provides another vantage on how these measures differ with respect to the activities of U.S. multinationals. By the IMF measure, nearly half of all U.S. multinational affiliates were located in countries with capital controls in 1982, though the fraction dropped to 21.0 percent by 1994. In contrast, 11.3 percent of all U.S. multinational affiliates were located in countries that Shatz classifies as imposing capital controls in 1982, a figure that falls to 3.1 percent by 1994. By both measures of capital account restrictions, affiliates in countries with capital controls have disproportionately fewer assets and sales and greater numbers of employees. Across all affiliate-year observations, as indicated in the bottom panel of Table 1, 8.5 percent of all observations were in countries with capital controls as measured by Shatz, while 34.0 percent were in countries with capital controls as measured by the IMF.

\section{Capital Account Restrictions and Foreign Direct Investment}

In order to isolate the impact of capital controls on the performance of American multinational firms, this section begins by considering one of the most basic elements of the cost of functioning under these regimes - the local borrowing environment. This analysis has the advantage of identifying how interest costs for the same borrower vary because of these regimes. This analysis of interest rates is followed by an examination of the degree to which multinational firms circumvent capital controls through various mechanisms. Finally, the section considers the overall effect of capital controls by presenting estimates of the impact of capital controls on investment levels.

\footnotetext{
11 This table displays information on capital controls for countries that are covered by both measures. In addition, the Shatz measure covers Taiwan, which imposes capital controls from 1982-1987. The IMF measure covers a sample of more than 150 countries. Most of those countries in this sample and not the Shatz sample are home to a very small number of affiliates.

12 The so-called Quinn index that was originally employed in Quinn (1997) is not employed here as it was not available on a continuous basis and only for two years - 1982 and 1988 - that were in the sample.
} 


\subsection{Interest rates}

Table 3 presents estimated coefficients from regressions estimating the determinants of interest rates. The dependent variable in the regressions reported in the first four columns is the interest rate paid on loans from unrelated parties. Interest costs are only collected in benchmark years, so the sample includes observations from 1982, 1989, and 1994. Columns one and two offer simple specifications, the independent variables including capital control indicators, dummy variables for parent companies, affiliate industries, and years, three powers of log GDP, and median total annual compensation per employee paid by American multinationals in country-year cells. ${ }^{13}$ The use of capital controls as measured by the IMF is associated with 2.3 percent higher interest rates; the use of capital controls as measured by Shatz is associated with 7.9 percent higher interest rates. ${ }^{14}$ Since the sample mean interest rate is just five percent, these are sizable effects.

The regressions reported in columns 3-8 of Table 3 add independent variables in order to control for observable affiliate and country attributes that might contribute to interest rate differences. In the regressions reported in columns 3 and 4, greater political riskiness and higher rates of local inflation are both associated with higher (dollar-denominated) interest rates, in both cases interpretable as reflecting the impact of greater uncertainty over the likelihood and level of ultimate repayment. After controlling for these additional variables, capital controls as measured by the IMF are associated with 1.2 percent higher interest rates, while capital controls as measured by Shatz are associated with 5.4 percent higher interest rates.

The regressions presented in columns 1-4 of Table 3 indicate that interest rates are higher in countries with capital controls. It is noteworthy that, since parent company fixed effects are included as independent variables, these interest rate effects appear between affiliates of the same companies. This evidence is, however, subject to the limitation that the denominator of the interest rate variable is total liabilities, including trade credits on which explicit interest is seldom

\footnotetext{
${ }^{13}$ Studies such as Eichengreen and Mody (2000a,b) examine the determinants of corporate borrowing spreads across countries and the impact of differing legal regimes on sovereign borrowing costs. The alternative of analyzing interest rates paid by multinational firms implicitly controls for a host of unobservable factors by comparing interest rates faced by the same company in different institutional environments. The absence of detailed data on affiliate borrowing makes it infeasible, however, to incorporate term structure considerations emphasized in papers such as Duffee (2002).

${ }^{14}$ All standard errors presented in the tables are clustered at the country-year level.
} 
paid. As a result, measured interest rates are somewhat low and may vary between countries due to trade financing practices.

Columns 5-8 of Table 3 report estimated coefficients from regressions designed to address this issue. The dependent variable is again the interest rate, in this case constructed as the ratio of total affiliate interest payments to other current liabilities and long-term debt, excluding trade accounts. The estimated capital market effects obtained using this dependent variable, reported in columns five and six, have the same signs and almost exactly the same magnitudes as those obtained using the first interest rate variable and reported in columns three and four.

Data limitations make it impossible to measure average interest rates paid to external sources when the denominator of the calculated interest rate excludes trade account debt. It is nonetheless possible to evaluate circuitously the difference between interest rates on parent loans and local loans, and the effect of capital controls on this difference, using a measure of interest rates that does not include trade account debt. Columns seven and eight of Table 3 present estimated coefficients from regressions in which the dependent variable is the same as that in the regressions reported in columns five and six, but adds two independent variables: the share of debt from non-parent sources, ${ }^{15}$ and the interaction between this share and measures of capital controls. If the cost of capital is higher in countries imposing capital controls, then the coefficient on the interaction between the share of debt from local sources and capital control measures should be positive, reflecting the extent of the difference.

The results indicate that greater borrowing from non-parent sources is associated with higher interest rates in countries imposing capital controls. The 0.0314 coefficient on the interaction of the IMF capital control measure and the share of debt borrowed from non-parent sources, reported in column 7, implies that interest rates on external debt (measured exclusive of trade credit) are 3.1 percent higher in countries with capital controls. The 0.0619 coefficient reported in column eight implies that interest rates are 6.2 percent higher in countries with capital controls as measured by Shatz. Since the mean interest rate on non-trade account borrowing is 7.7 percent, these are sizable effects and consistent with the earlier analysis. 


\subsection{Profit extraction}

Multinational firms whose affiliates are located in countries with capital controls have incentives to find creative ways to extract profits for deployment elsewhere. Profits can be relocated by changing the locations in which they are reported, and by changing patterns of profit remittances much as multinational firms respond to taxation.

\subsubsection{Transfer pricing}

It is possible for multinational firms to sidestep repatriation restrictions by manipulating the prices at which foreign affiliates trade with their American parent companies, since overinvoicing parent exports to affiliates, or underinvoicing parent imports from affiliates, serves to relocate profits. The same tactics reduce total tax liabilities when used to relocate taxable income from high-tax to low-tax jurisdictions. Governments typically insist that firms use arm's length prices in trade with other members of the same controlled group, but such prices are notoriously difficult to enforce, particularly when (as is often the case for multinational firms) traded goods have unique characteristics that make it difficult to identify perfectly comparable items. As a result, affiliates located in countries with high tax rates or binding repatriation controls are likely to run larger trade deficits (or smaller trade surpluses) with their parent companies than would otherwise be the case, since firms have incentives to structure and record such trades in ways that relocate as many profits as possible. There is an extensive literature that analyzes the reported profitability patterns of American multinational firms, finding that affiliates located in high-tax countries tend to report lower profit rates than do those located in low-tax countries. ${ }^{16}$

Table 4 presents results of specifications similar to those used to study the impact of taxes in which the dependent variable is the rate of return on affiliate equity. The sample covers all years from 1982 to 1995 . In a smoothly functioning competitive market the expected rate of return should be the same everywhere, but in a setting in which firms systematically understate

\footnotetext{
${ }^{15}$ The share of debt from non-parent sources equals one minus the ratio of current liabilities and long-term debt owed to the parent to total current liabilities and long-term debt.

${ }^{16}$ See, for example, Grubert and Mutti (1991), Hines and Rice (1994), and the literature surveyed by Hines (1999).
} 
profits earned in high-tax countries and in countries with capital controls, there should be a negative association between profit rates and tax rates or the use of capital controls.

The -0.2075 coefficient reported in column one of Table 4 implies that ten percent higher tax rates are associated with 2.1 percent lower profit rates, controlling for parent company, affiliate industry, year, three powers of log GDP, and median employee compensation paid by U.S. multinationals. The magnitude of this effect is similar to that reported elsewhere in the transfer-pricing literature, and corresponds to commonly observed avoidance methods. The regression reported in column two indicates that capital controls as measured by the IMF have insignificant effects on reported profits, whereas the -0.0472 coefficient in the regression reported in column three indicates that affiliates located in countries with capital controls as measured by Shatz have 4.7 percent lower reported profit rates. Together with the estimated 0.1959 coefficient on local tax rates, the capital control coefficient implies that the imposition of capital controls has the same (negative) effect on reported profits as would a 24.1 percent higher tax rate.

Columns four and five of Table 4 report estimated coefficients from regressions in which the sample is restricted to affiliates in countries that remove capital controls (as defined by Shatz) during the sample period, and the regressions include affiliate fixed effects, thereby estimating the impact of capital controls on the basis only of changes induced by their removal. ${ }^{17}$ This necessarily entails a much smaller sample size than that used in the regressions reported in columns 1-3. The estimated tax effects, which are likewise estimated based on changes, are comparable in sign and magnitude to those appearing in columns 1-3. The 0.0823 coefficient on the post liberalization dummy variable in the regression reported in column five implies that the removal of capital controls is associated with 8.2 percent higher affiliate profit rates, though this effect is not statistically significant. In order to assess the reasonableness of the estimated impact of capital controls on reported profitability, it is useful to consider more directly their impact on transfer pricing.

The regressions presented in Table 5 analyze the effect of capital controls on a measure of the trade balance of U.S. parents with affiliates in particular industry/country/year cells. The 
dependent variable in these specifications is a ratio, the numerator of which is the difference between total U.S.-parent exports to their foreign affiliates and total U.S.-parent imports from foreign affiliates; the denominator is the sum of these exports and imports. This variable is calculated by summing trade between parents and affiliates in country/industry/year cells over the 1982-1995 period, and omitting cells for which there is zero trade (and for which the ratio has a denominator of zero). Clausing (2001) develops this measure at an aggregate country level and employs it to explore the extent to which firms relocate profits in response to local tax incentives.

Tax rate differences encourage American parent companies to run larger trade surpluses with their affiliates in high-tax countries than with those in low-tax countries, since doing so reduces total tax burdens. The estimated positive coefficients on the tax rate variable in the regressions reported in Table 5 are consistent with these incentives, and indeed, are consistent with the aggregate country results reported by Clausing (2001). In the regression reported in column one, ten percent higher local tax rates are associated with 3.7 percent greater parent trade surpluses, controlling for industry and year fixed effects, three powers of log GDP, and median employee compensation paid by U.S. multinationals. The estimated tax effect is little changed by the introduction of capital control measures in the regressions reported in columns 2-3. Capital controls as measured by the IMF are associated with 3.2 percent greater parent trade surpluses, though this effect is marginally significant; the Shatz capital control variable is associated with a larger 7.1 percent impact on parent trade surpluses.

It is instructive to relate the trade effect of capital controls as captured by the Shatz variable to the profit shifting results above. The 0.0708 and 0.3793 coefficients in the regression reported in column three of Table 5 together imply that capital controls have the same trade surplus impact as would 18.7 percent higher local tax rates. Viewed differently, the 0.0708 coefficient together with the $\$ 240$ billion of reported 1994 trade between U.S. parent firms and their foreign affiliates implies that parent trade surpluses with their affiliates would be elevated by $\$ 17$ billion if all foreign countries imposed capital controls. The aggregate owner's equity in U.S.-owned foreign affiliates was $\$ 819$ billion in the same year, so the -0.0472 coefficient from

\footnotetext{
${ }^{17}$ Liberalizing countries include Argentina (1990), Brazil (1992), Chile (1992), Colombia (1992), Ecuador (1993), Egypt (1992), Greece (1987), Peru (1993), Philippines (1992), Taiwan (1988), and Venezuela (1990).
} 
column three in Table 4 implies that aggregate reported affiliate profits would be reduced by $\$ 39$ billion if all countries adopted capital controls. Hence the observable effect on trade with parent companies accounts for slightly less than half of the measured impact of capital controls on affiliate profitability. Since affiliates are able to use financing devices, trade with related parties other than parent companies, and other methods to relocate reported profits, the evidence of capital control effects on profitability and trade surpluses is quite consistent.

\subsubsection{Dividend repatriations}

Firms that are restricted in their ability to remit dividends commonly find that the shadow value of local retained earnings is less than the value of capital deployed elsewhere, so they have incentives to remove profits if possible. Capital controls typically include repatriation restrictions that operate on annual bases, thereby indirectly encouraging affiliates to remit dividends to their parent companies every year, lest low-cost repatriation opportunities otherwise be lost. For example, Brazilian affiliates in the 1980s were subject to 40 percent or higher tax rates on repatriations averaging more than 13 percent of registered investment over any threeyear period. ${ }^{18}$ In order to investigate the extent to which firms respond to this incentive, the regressions reported in Table 6 are logit specifications in which the dependent variable is a dummy equal to one if an affiliate pays a dividend to its parent in a particular year, and zero otherwise. The sample again covers the 1982-1995 period. Country tax rates are included as independent variables (since higher tax rates generally reduce the cost of paying dividends to American parent companies), as are parent and year fixed effects, three powers of log GDP, and median employee compensation paid by U.S. multinationals.

The regression reported in column one of Table 6 indicates that higher country tax rates and higher affiliate return on assets are associated with significantly greater likelihoods of paying dividends. The regressions reported in columns 2-3 of Table 6 indicate that the chances of paying a dividend are significantly higher in countries with capital controls as measured both by the IMF and by Shatz. The 0.3589 coefficient in column three implies that the imposition of capital controls (as measured by Shatz) has the same effect on the likelihood of paying dividends as does a 7.7 percent higher return on assets, or a 35 percent higher local tax rate. The estimated

\footnotetext{
${ }^{18}$ See Bentley (1985) for further details.
} 
coefficients imply that an affiliate with mean values of the other independent variables is 9.8 percent more likely to pay a dividend if it is located in a country imposing capital controls than it would be if located in a country that does not control capital flows, ${ }^{19}$ a sizable effect given that such an average affiliate has only a 53.3 percent chance of paying a dividend at all.

Columns 4-5 of Table 6 report estimated coefficients from regressions in which the sample is restricted to affiliates in countries that remove capital controls, and the inclusion of affiliate fixed effects implies that the impact of capital controls is identified on the basis of changes induced by their removal. The sample size is therefore considerably smaller than the samples used for the estimation reported in columns 1-3. The estimated tax effects reported in columns 4-5, which are likewise estimated based on changes, are somewhat larger than those reported in columns 1-3, while the estimated impact of changes in return on assets is of comparable size. The -0.5701 coefficient reported in column five indicates that the removal of capital controls is associated with significantly reduced likelihood of remitting dividends to parent companies. The estimated impact of capital account liberalization is equal in magnitude to that of 14 percent lower return on assets or 25 percent lower tax rates and at mean values of other independent variables implies that the removal of capital controls reduces by 11.6 percent the chance that an affiliate will pay a dividend.

Firms with incentives to repatriate funds on a regular basis are likely to have dividend streams that are less responsive to changing conditions than are remittances by unconstrained affiliates. In order to test this possibility, it is convenient to estimate a standard Lintner model of dividend payments by foreign affiliates, ${ }^{20}$ in which current dividends are regressed on current after-tax income and lagged dividends. The concept behind the Lintner model is that target dividend levels are functions of current income, but that actual dividends adjust only slowly to desired dividends. The estimated adjustment parameter is equal to one minus the coefficient on lagged dividends, while the estimated steady state dividend payout ratio equals the ratio of the coefficient on net income and the adjustment parameter.

\footnotetext{
${ }^{19}$ This implied marginal effect of capital controls is estimated from a model that includes among its independent variables only one power of GDP, since the inclusion of two additional powers of GDP creates such multicolinearity that marginal effects become very difficult to estimate.

${ }^{20}$ For an elaboration of the Lintner dividend model, and its application to remittances by foreign affiliates, see Desai, Foley and Hines (2001, 2002).
} 
The results indicate that dividend repatriations adjust more slowly to income changes in capital control countries than they do in other countries. Columns 1-6 of Table 7 report estimated coefficients from Lintner specifications run on the whole sample with and without parent and affiliate fixed effects. The results are similar to those in Desai, Foley and Hines (2001), the estimated 0.2588 coefficient on lagged dividends in column 1 for example implying an adjustment parameter of 0.74. Columns 3-4 report specifications adding interactions of net income and lagged dividends with dummy variables indicating capital controls as measured by the IMF; these interactions permit the effects of net income and lagged dividends to differ between affiliates located in countries with and without capital controls. The positive estimated coefficients on the interaction of lagged dividends and the IMF dummy imply that dividend remittances from affiliates in countries with capital controls adjust more slowly to income changes than do remittances from affiliates in other countries, though the difference is not statistically significant.

Columns 5-6 of Table 7 report estimates using the Shatz measure of capital controls, and in these specifications, adjustment parameters and implied steady-state payout ratios differ sharply between affiliates located in capital control countries and affiliates located elsewhere. The estimates reported in column 5 imply that affiliates in capital control countries have adjustment parameters of 0.46 , while those in countries without capital controls have adjustment parameters of 0.79. Affiliates in capital control countries have steady-state payout ratios of 65.4 percent, compared with payout ratios of 54 percent for other affiliates. Since countries imposing capital controls typically limit the size of permitted dividend repatriations, it is not surprising that there is little difference in implied steady-state payout ratios. What is more telling is that dividend repatriations respond more sluggishly to income changes in countries with capital controls, which is consistent with behavior that is driven by a desire to extract profits.

Columns 7-10 of Table 7 report coefficients from dividend payout equations estimated on the sample of affiliates located in countries that liberalize their capital account restrictions during the sample period. The estimated effects of net income and lagged dividends are similar to those reported in columns 1-6, while the interaction of the post liberalization dummy variable and lagged dividends is negative, implying that dividends exhibit considerably less persistence in post-liberalization periods. The results reported in columns 9 and 10 imply much smaller 
dividend adjustment parameters in periods without capital controls, which is consistent with the evidence reported in Table 6 and with the incentives created by repatriation restrictions. Furthermore, the regularity of dividend payments from affiliates in countries with capital controls is unlikely to be a function simply of omitted variables responsible for the introduction of the controls.

\subsection{Investment}

If local borrowing rates were unaffected by capital controls and capital control evasion technologies were costless, investment by multinational firms need not be affected by capital controls. As demonstrated above, however, the macroeconomic effects of capital controls include elevating interest rates to levels that may make local debt finance unattractive. Similarly, Tables 4-7 indicate that firms engage in avoidance strategies that are comparable to the strategies they employ in response to significant differences in tax rates. Given the various other tax and non-tax motivations that would otherwise guide dividend repatriation policies and intercompany income allocation, these actions are likely to be quite costly. Consequently, it is useful to measure the extent to which capital controls are accompanied by reduced foreign investment levels.

Table 8 presents estimates of the effects of capital controls on one measure of the magnitude of foreign direct investment by U.S. multinationals, the size of affiliates at first appearance. The sample consists of affiliates the first time that they appear in the BEA data between 1983-1995, so each affiliate is included just once. The specifications reported in columns 1-3 include dummy variables for multinational parents, affiliate industry, and years, as well as three powers of log GDP and median employee compensation paid by U.S.

multinationals. The -0.3020 coefficient on country tax rates implies that ten percent higher tax rates are associated with three percent smaller affiliates, an effect and magnitude that is consistent with the evidence reported in the literature on tax effects on foreign direct investment. The -0.1590 coefficient in column 2 of Table 8 indicates that affiliate assets, at first appearance, are 15.9 percent smaller in countries with capital controls as measured by the IMF than they are in countries without capital controls. Estimates using the Shatz capital control measure, reported in column 3, imply that affiliates in capital control countries are 12.7 percent smaller. 
Columns 4-5 of Table 8 present estimates of the determinants of asset size changes for affiliates in countries that liberalize their capital account restrictions. These regressions include observations of affiliates not just at their first appearances but over the entire sample period, though the sample is limited to affiliates located in countries that remove capital controls. The specifications include affiliate fixed effects and year dummies as independent variables, so the effects of tax rates and capital controls are identified from changes rather than levels. The estimated tax rate effects are paradoxically positive, though the 0.1562 coefficient on the post liberalization dummy variable in the regression reported in column five is quite consistent with the magnitudes of the estimated effects reported in columns 2-3.

The results reported in Table 8 imply that affiliates located in countries with capital controls are smaller relative to affiliates located in other countries. As discussed above, it is possible that this initial size is ultimately offset by higher growth through forced retention of earnings. In order to examine this possibility it is useful to consider whether affiliates retain greater earnings in countries with capital controls. While other results indicate that multinationals respond to capital controls by smoothing dividends and shifting profits, it is possible that these efforts are incomplete, leaving affiliates in countries with capital controls to grow ultimately to large sizes.

Table 9 presents regressions that track this dynamic, using data from the 1982, 1989, and 1994 Benchmark Surveys. The dependent variable in these regressions is the ratio of retained earnings to total affiliate assets, and the independent variables include local tax rates, dummy variables for multinational parents, affiliate industries, and years, three powers of log GDP, and median employee compensation paid by U.S. multinationals. Capital controls are associated with reduced retained earnings in the specifications reported in columns 2 and 3 , the -0.0661 coefficient in column three corresponding to 6.6 percent lower ratios of retained earnings to total assets. Since the mean ratio of retained earnings to total assets is 17.9 percent, it follows that this is a sizable effect, and that multinational affiliates in countries with capital controls not only begin with fewer assets than other affiliates, but also accumulate retained earnings at slower rates.

\section{Conclusion}


This paper offers evidence that the foreign affiliates of American multinational firms circumvent capital controls by regularizing dividend remittances and relocating profits. Evading capital controls in this way is costly given the tax and other business considerations that would otherwise guide dividend repatriations and trade between related parties. Countries imposing capital controls have significantly higher interest rates than do otherwise-similar countries without capital controls. Multinational firms contemplating new investments in countries with capital controls therefore face high costs of local borrowing and significant costs associated with the actions necessary to avoid the impact of capital controls, and as a result, their investment levels are significantly reduced. Capital account liberalizations are associated with reversals in these patterns. While this paper evaluates the activities of foreign affiliates of American multinational firms, the costs associated with capital controls undoubtedly discourage many potential investors from establishing affiliates in the first place.

Since countries imposing capital controls differ in many ways from those that do not, it is infeasible to control for all the relevant differences in evaluating the impact of capital controls. As a result, the smaller asset demands of American affiliates in countries imposing capital controls might stem either from the capital controls themselves or from the economic conditions that motivate governments to impose the controls. Details of the behavior of multinational firms offer the prospect of distinguishing these interpretations, since some aspects of this behavior are unlikely to be a function of the factors that motivate governments to impose the controls. Evidence of the effects of capital controls on profit reallocation and dividend repatriation implies that firms behave in a manner that is consistent with higher local costs of capital, suggesting that the observed effects on assets and retained earnings reflect the impact of policies and not merely the conditions responsible for the policies.

In addition to providing a window on the aggregate effects of capital controls and liberalizations on investment behavior, the evidence on how multinationals employ internal markets to circumvent these controls suggests that capital controls have distributional consequences. Firms without access to internal capital markets are likely to be hardest hit by capital account restrictions. Consequently, capital controls not only raise the costs of capital faced by smaller domestic firms but also likely disadvantage them relative to larger multinational firms against which they compete. 


\section{References}

Aitken, Brian J. and Ann E. Harrison (1999). Do domestic firms benefit from direct foreign investment? Evidence from Venezuela, American Economic Review,89:605-618.

Aizenman, Joshua (2002). Volatility, employment and the patterns of FDI in emerging markets, Journal of Development Economics, forthcoming.

Alesina, Alberto, Vittorio Grilli and Gian Maria Milesi-Ferretti (1994). The political economy of capital controls, in Leonardo Leiderman and Assaf Razin (eds.), Capital Mobility: The Impact on Consumption, Investment and Growth. Cambridge: Cambridge University Press, 289-328.

Allayannis, George, Gregory W. Brown, and Leora F. Klapper (2003). Capital structure and financial risk: Evidence from foreign debt use in East Asia, Journal of Finance, 58:26672710 .

Arteta, Carlos, Barry Eichengreen and Charles Wyplosz (2001). When does capital account liberalization help more than it hurts? NBER Working Paper No. 8414.

Auguste, Sebastian, Kathryn M. E. Dominguez, Herman Kamil and Linda Tesar (2003). Crossborder trading as a mechanism for capital flight: ADRs and the Argentine crisis, NBER Working Paper No. 9343.

Beck, Thorsten, Asli Demirguc-Kunt, and Ross Levine (2000). A new database on financial development and structure, World Bank Economic Review, 14:597-605.

Bekaert, Geert and Campbell Harvey (2000). Foreign speculators and emerging equity markets, Journal of Finance, 55:565-613.

Bekaert, Geert, Campbell Harvey and Christian Lundblad (2002). Does financial liberalization spur growth? NBER Working Paper No. 8245.

Bentley, Philip (1985). A World Guide to Exchange Control Regulations. London: Euromoney Publications.

Bhagwati, Jagdish (1998). The capital myth: The difference between trade in widgets and dollars, Foreign Affairs, 77:7-12.

Chari, Anusha and Peter Blair Henry (2002). Capital account liberalization: Allocative efficiency or animal spirits? NBER Working Paper No. 8908.

Chinn, Menzie D. and Hiro Ito (2002). Capital account liberalization, institutions and financial development: Cross-country evidence, NBER Working Paper No. 8967.

Clausing, Kimberly A. (2001). The impact of transfer pricing on intrafirm trade, in James R. Hines (ed.), International Taxation and Multinational Activity. Chicago: University of Chicago Press, 173-194. 
Desai, Mihir A., C. Fritz Foley and Kristin J. Forbes (2003). Shelters from the storm: Multinational and local firm responses to currency crises, Harvard Business School Working Paper.

Desai, Mihir A., C. Fritz Foley and James R. Hines Jr. (2001). Repatriation taxes and dividend distortions, National Tax Journal, 54:829-851.

Desai, Mihir A., C. Fritz Foley and James R. Hines Jr. (2002). Dividend policy inside the firm, NBER Working Paper No. 8698.

Desai, Mihir A., C. Fritz Foley and James R. Hines Jr. (2003). A multinational perspective on capital structure choice and internal capital markets, Journal of Finance, forthcoming.

Desai, Mihir A., and James R. Hines Jr. (1999). 'Basket' cases: Tax incentives and international joint venture participation by American multinational firms, Journal of Public Economics, 71:379-402.

Dooley, Michael and Peter Isard (1980). Capital controls, political risk and interest-rate parity, Journal of Political Economy, 88:370-384.

Duffee, Gregory R. (2002). Term premia and interest rate forecasts in affine models, Journal of Finance, 57:405-443.

Edison, Hali J., Michael W. Klein, Luca Ricci and Torsten Sloek (2002). Capital account liberalization and economic performance: Survey and synthesis, NBER Working Paper No. 9100.

Edwards, Sebastian (2001). Capital flows and economic performance: Are emerging economies different? NBER Working Paper No. 8076.

Eichengreen, Barry (2001). Capital account liberalization: What do the cross-country studies tell us? World Bank Economic Review, 15:341-365.

Eichengreen, Barry and Ashoka Mody (2000a). What explains spreads on emerging market debt? in Sebastian Edwards (ed.), Capital Flows and The Emerging Economies: Theory, Evidence, and Controversies. Chicago: The University of Chicago Press, 107-136.

Eichengreen, Barry and Ashoka Mody (2000b). Would collective action clauses raise borrowing costs? NBER Working Paper No. 7458.

Fischer, Stanley (1998). Capital account liberalization and the role of the IMF, Princeton Essays in International Finance, 207:1-10.

Forbes, Kristin J. (2003). One cost of the Chilean capital controls: Increased financial constraints for smaller trade firms, NBER Working Paper No. 9777.

Grilli, Vittorio and Gian Maria Milesi-Ferretti (1995). Economic effects and structural determinants of capital controls, IMF Staff Papers, 42:517-551. 
Grubert, Harry and John Mutti (1991). Taxes, tariffs and transfer pricing in multinational corporate decision making, Review of Economics and Statistics, 73:285-293.

Henry, Peter Blair (2000). Do stock market liberalizations cause investment booms? Journal of Financial Economics, 58:301-334.

Hines, James R., Jr. (1999). Lessons from behavioral responses to international taxation, National Tax Journal, 52:305-322.

Hines, James R., Jr., and Eric M. Rice (1994). Fiscal paradise: Foreign tax havens and American business, Quarterly Journal of Economics, 109:149-182.

Johnson, Simon and Todd Mitton (2003). Cronyism and capital controls: Evidence from Malaysia, Journal of Financial Economics, 67:351-382.

Johnson, Simon, Peter Boone, Alasdair Breach and Eric Friedman (2000). Corporate governance in the Asian financial crisis, Journal of Financial Economics, 58:141-186.

Kedia, Simi, and Abon Mozumdar (2003). Foreign currency denominated debt: An empirical examination, Journal of Business, 76:521-546.

Mitton, Todd (2002). A cross-firm analysis of the impact of corporate governance on the East Asian financial crisis, Journal of Financial Economics, 64:215-241.

Morck, Randall K., David A. Strangeland, and Bernard Yeung (1998). Inherited wealth, corporate control and economic growth: The Canadian disease, NBER Working Paper No. 6814 .

Quinn, Dennis P. (1997). The correlates of changes in international financial regulation, American Political Science Review, 91:531-551.

Quinn, Dennis P., Carla Inclan, and A. Maria Toyoda (2001). How and where capital account liberalization leads to economic growth, Georgetown University Working Paper.

Rajan, Raghuram G. and Luigi Zingales (2003). The great reversals: The politics of financial development in the Twentieth century. Journal of Financial Economics, 69:5-50.

Rodrik, Dani (1998). Who needs capital account convertibility? Princeton Essays in International Finance, 207:55-65.

Shatz, Howard (2000). The location of U.S. multinational affiliates, Harvard University Ph.D. Thesis.

Stulz, Rene (1995). The cost of capital in internationally integrated markets: The case of Nestle, Journal of Applied Corporate Finance, 8:30-39.

Stulz, Rene (1999). International portfolio flows and security markets, in Martin Feldstein (ed.) International Capital Flows. Chicago, University of Chicago Press, 257-293. 


\begin{tabular}{|c|c|c|c|c|}
\hline & & \multicolumn{3}{|c|}{ Benchmark Years } \\
\hline & & 1982 & 1989 & $\underline{1994}$ \\
\hline Number of Affiliates & & 18,579 & 18,899 & 20,898 \\
\hline Median Sales & & 10,875 & 12,788 & 14,079 \\
\hline Median Assets & & 9,823 & 13,120 & 14,385 \\
\hline Median Employees & & 79 & 64 & 68 \\
\hline \multicolumn{5}{|l|}{ Share of Activity in Countries with } \\
\hline \multirow{2}{*}{ Number of Affiliates } & IMF & $46.9 \%$ & $40.4 \%$ & $21.0 \%$ \\
\hline & Shatz & $11.3 \%$ & $9.8 \%$ & $3.1 \%$ \\
\hline \multirow{2}{*}{ Assets } & IMF & $38.2 \%$ & $28.4 \%$ & $11.6 \%$ \\
\hline & Shatz & $6.4 \%$ & $4.7 \%$ & $1.1 \%$ \\
\hline \multirow{2}{*}{ Sales } & IMF & $35.9 \%$ & $30.0 \%$ & $13.5 \%$ \\
\hline & Shatz & $6.3 \%$ & $6.4 \%$ & $1.2 \%$ \\
\hline \multirow{2}{*}{ Employees } & IMF & $47.8 \%$ & $40.8 \%$ & $28.7 \%$ \\
\hline & Shatz & $14.2 \%$ & $13.1 \%$ & $3.8 \%$ \\
\hline
\end{tabular}

\section{Descriptive Statistics for Variables}

Parent Trade Surplus

Net Income/Owners' Equity

Dividend Dummy

Dividends

Net Income

Return on Assets

Log of Assets

Country Tax Rate

IMF Capital Control Dummy

Shatz Capital Control Dummy

Retained Earnings/Total Assets

Interest Rate on External Borrowing

Interest Rate on Non-Trade Account Borrowing

Share of Debt from Non-Parent Sources

Private Credit

Political Risk

Rate of Inflation

\begin{tabular}{r} 
Mean \\
\hline 0.5133 \\
0.1655 \\
0.2946 \\
5,024 \\
6,222 \\
0.0565 \\
10.1245 \\
0.3367 \\
0.3441 \\
0.0845 \\
0.1794 \\
0.0493 \\
0.0765 \\
0.8148 \\
0.7927 \\
0.2359 \\
0.5572
\end{tabular}

Median
0.9762
0.1456

St. Dev

0.6976

0.2704

0.4559

32,445

21,614

0.1985

1.4741

0.1266

0.4751

0.2781

0.3367

0.0922

0.1322

0.2796

0.4478

0.1215

3.1066

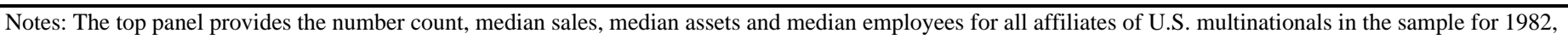
1989, 1994. In 1982, 1989, and 1994, Benchmark Surveys were conducted and, consequently, the cutoff for inclusion in the sample is lower than other years as

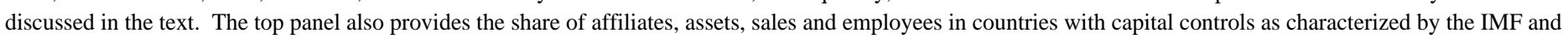

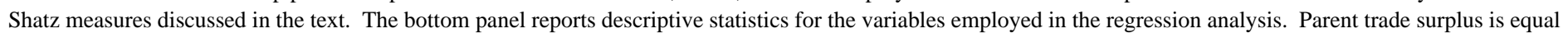
to the difference between parent exports to the affiliate and parent imports from the affiliate divided by the sum of these two values. Net income, owners' equity,

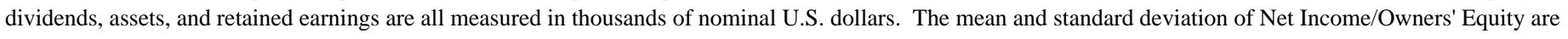

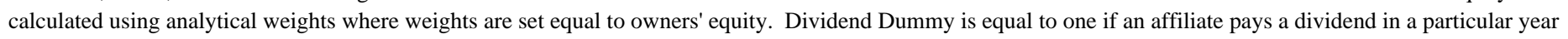

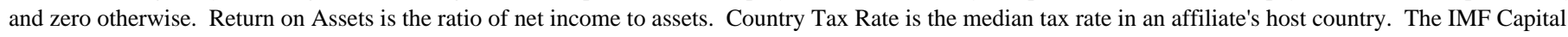
Control Dummy and the Shatz Capital Control Dummy are dummies equal to one if a country imposes capital controls and zero otherwise. The Interest Rate on

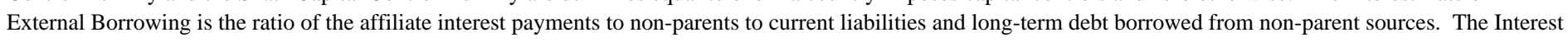

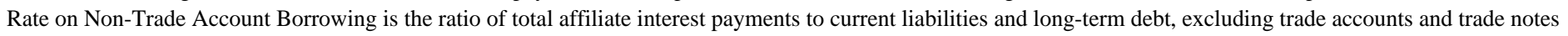

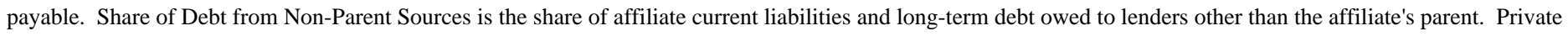

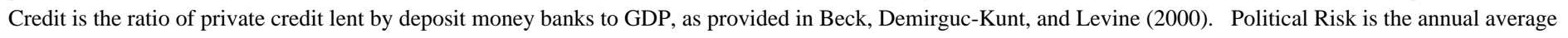

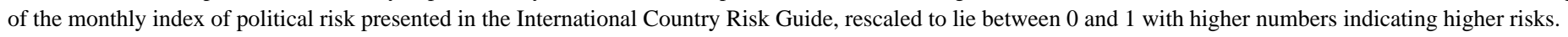
Rate of Inflation is the contemporaneous percentage change in the GDP deflator of an affiliate's host country. 
Table 2

Descriptive Statistics of Capital Control Measures, for those countries measured by Shatz

\begin{tabular}{|c|c|c|c|c|c|}
\hline & \multicolumn{2}{|c|}{ Capital Control Measure } & & \multicolumn{2}{|c|}{ Capital Control Measure } \\
\hline & $\begin{array}{c}\text { IMF Measure } \\
\text { (covers 1982-1995) }\end{array}$ & $\begin{array}{c}\text { Shatz Measure } \\
\text { (covers 1982-1995) }\end{array}$ & & $\begin{array}{c}\text { IMF Measure } \\
\text { (covers 1982-1995) }\end{array}$ & $\begin{array}{c}\text { Shatz Measure } \\
\text { (covers 1982-1995) }\end{array}$ \\
\hline Argentina & 1982-1992 & 1982-1989 & Italy & 1982-1989 & \\
\hline Austria & $1982-1990$ & & Japan & & \\
\hline Bahamas & 1982-1995 & & Korea & 1982-1995 & \\
\hline Brazil & 1982-1995 & 1982-1991 & Netherlands & & \\
\hline Canada & & & Netherlands Antilles & 1982-1995 & \\
\hline Chile & 1982-1995 & 1982-1991 & New Zealand & 1982-1983 & \\
\hline China & 1982-1995 & 1982-1995 & Nigeria & 1982-1995 & 1982-1995 \\
\hline Colombia & 1982-1995 & 1982-1991 & Norway & 1982-1994 & \\
\hline Egypt & 1982-1995 & 1982-1991 & Saudi Arabia & & \\
\hline Finland & 1982-1990 & & Singapore & & \\
\hline France & 1982-1989 & & South Africa & 1982-1995 & \\
\hline Germany & & & Spain & 1982-1993 & \\
\hline Greece & 1982-1995 & 1982-1986 & Sweden & 1982-1992 & \\
\hline Guatemala & 1982-1988 & & Switzerland & $\begin{array}{c}\text { none in 1992-1995, } \\
\text { other years NA }\end{array}$ & \\
\hline Honduras & 1982-1992 & & Thailand & 1982-1995 & \\
\hline Hong Kong & & & Trinidad and Tobago & 1982-1993 & \\
\hline India & 1982-1995 & 1982-1995 & Turkey & 1982-1995 & \\
\hline
\end{tabular}


Table 3

Capital Controls and Local Borrowing Rates

Dependent Variable: $\quad$ Interest Rate on External Borrowing

\begin{tabular}{|c|c|c|c|c|c|c|c|c|}
\hline & & \multicolumn{4}{|c|}{ Borrowing (from all sources) } \\
\hline & (1) & (2) & (3) & (4) & (5) & (6) & (7) & (8) \\
\hline Constant & $\begin{array}{r}3.5830 \\
(3.2431)\end{array}$ & $\begin{array}{c}12.2232 \\
(5.3339)\end{array}$ & $\begin{array}{r}0.7601 \\
(4.4529)\end{array}$ & $\begin{array}{r}8.8616 \\
(5.9529)\end{array}$ & $\begin{array}{r}6.2761 \\
(4.2771)\end{array}$ & $\begin{array}{r}17.3656 \\
(6.5060)\end{array}$ & $\begin{array}{r}5.4139 \\
(4.3553)\end{array}$ & $\begin{array}{r}16.6440 \\
(6.4980)\end{array}$ \\
\hline Country tax rate & & & $\begin{array}{r}-0.0719 \\
(0.0611)\end{array}$ & $\begin{array}{r}-0.0461 \\
(0.0499)\end{array}$ & $\begin{array}{r}-0.0570 \\
(0.0519)\end{array}$ & $\begin{array}{c}-0.0227 \\
(0.0427)\end{array}$ & $\begin{array}{r}-0.0600 \\
(0.0539)\end{array}$ & $\begin{array}{r}-0.0262 \\
(0.0443)\end{array}$ \\
\hline Private Credit & & & $\begin{array}{r}-0.0084 \\
(0.0083)\end{array}$ & $\begin{array}{r}-0.0068 \\
(0.0084)\end{array}$ & $\begin{array}{r}-0.0042 \\
(0.0094)\end{array}$ & $\begin{array}{r}-0.0010 \\
(0.0102)\end{array}$ & $\begin{array}{r}-0.0052 \\
(0.0094)\end{array}$ & $\begin{array}{r}-0.0023 \\
(0.0100)\end{array}$ \\
\hline Political Risk & & & $\begin{array}{r}0.1189 \\
(0.0469)\end{array}$ & $\begin{array}{r}0.0655 \\
(0.0342)\end{array}$ & $\begin{array}{r}0.1641 \\
(0.0502)\end{array}$ & $\begin{array}{r}0.1255 \\
(0.0420)\end{array}$ & $\begin{array}{r}0.1746 \\
(0.0516)\end{array}$ & $\begin{array}{r}0.1284 \\
(0.0428)\end{array}$ \\
\hline Rate of inflation & & & $\begin{array}{r}0.0056 \\
(0.0017)\end{array}$ & $\begin{array}{r}0.0050 \\
(0.0013)\end{array}$ & $\begin{array}{r}0.0050 \\
(0.0015)\end{array}$ & $\begin{array}{r}0.0045 \\
(0.0014)\end{array}$ & $\begin{array}{r}0.0050 \\
(0.0016)\end{array}$ & $\begin{array}{r}0.0044 \\
(0.0014)\end{array}$ \\
\hline IMF Capital Control Dummy & $\begin{array}{r}0.0229 \\
(0.0076)\end{array}$ & & $\begin{array}{r}0.0117 \\
(0.0053)\end{array}$ & & $\begin{array}{r}0.0160 \\
(0.0058)\end{array}$ & & $\begin{array}{r}-0.0104 \\
(0.0078)\end{array}$ & \\
\hline Shatz Captial Control Dummy & & $\begin{array}{r}0.0785 \\
(0.0227)\end{array}$ & & $\begin{array}{r}0.0544 \\
(0.0197)\end{array}$ & & $\begin{array}{r}0.0542 \\
(0.0190)\end{array}$ & & $\begin{array}{r}0.0073 \\
(0.0168)\end{array}$ \\
\hline $\begin{array}{l}\text { Share of Debt from Non- } \\
\text { Parent Sources }\end{array}$ & & & & & & & $\begin{array}{r}-0.0046 \\
(0.0046)\end{array}$ & $\begin{array}{r}0.0016 \\
(0.0049)\end{array}$ \\
\hline $\begin{array}{l}\text { Share of Debt from Non- } \\
\text { Parent Sources Interacted with } \\
\text { IMF Capital Control Dummy }\end{array}$ & & & & & & & $\begin{array}{r}0.0314 \\
(0.0099)\end{array}$ & \\
\hline $\begin{array}{l}\text { Share of Debt from Non- } \\
\text { Parent Sources Interacted with } \\
\text { Shatz Capital Control Dummy }\end{array}$ & & & & & & & & $\begin{array}{r}0.0619 \\
(0.0280)\end{array}$ \\
\hline $\begin{array}{l}\text { Parent, industry, and year } \\
\text { fixed effects? }\end{array}$ & $\mathrm{Y}$ & Y & $\mathrm{Y}$ & $\mathrm{Y}$ & Y & Y & Y & Y \\
\hline GDP and wage controls? & $\mathrm{Y}$ & $\mathrm{Y}$ & $\mathrm{Y}$ & $\mathrm{Y}$ & $\mathrm{Y}$ & $\mathrm{Y}$ & $\mathrm{Y}$ & $\mathrm{Y}$ \\
\hline No. of Obs. & 20,378 & 20,357 & 18,413 & 18,553 & 18,473 & 18,549 & 17,982 & 18,081 \\
\hline R-Squared & 0.2053 & 0.2382 & 0.2531 & 0.2671 & 0.2699 & 0.2729 & 0.2721 & 0.2763 \\
\hline
\end{tabular}

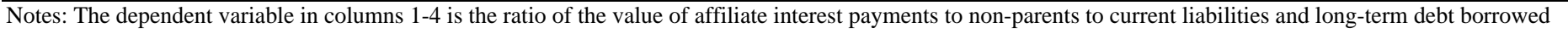

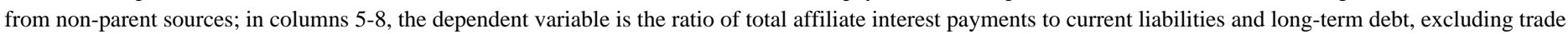

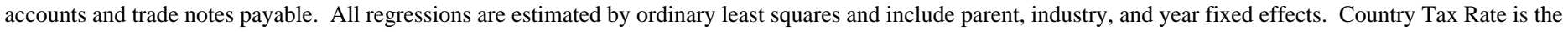

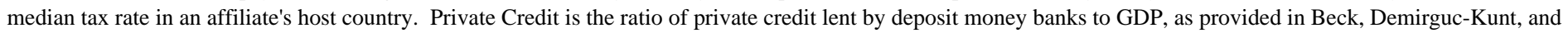

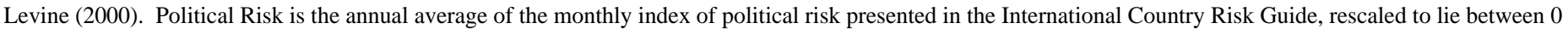

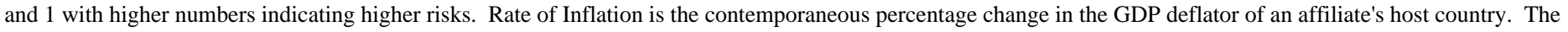

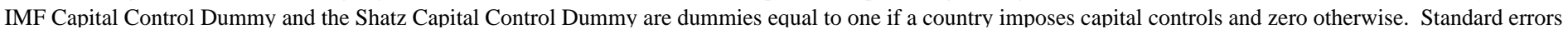
that correct for clustering of errors across observations in country/year cells are presented in parentheses. 
Table 4

\section{Capital Controls and Transfer Pricing Activities of U.S. Multinationals}

\begin{tabular}{|c|c|c|c|c|c|}
\hline \multirow{2}{*}{$\begin{array}{l}\text { Dependent Variable: Net } \\
\text { Income/Owners' Equity }\end{array}$} & \multicolumn{3}{|c|}{ Full Sample } & \multicolumn{2}{|c|}{ Liberalizing Countries } \\
\hline & (1) & $(2)$ & (3) & (4) & (5) \\
\hline Constant & $\begin{array}{r}-35.4662 \\
(8.4114)\end{array}$ & $\begin{array}{r}-18.6025 \\
(8.0517)\end{array}$ & $\begin{array}{r}-45.2557 \\
(11.6224)\end{array}$ & $\begin{array}{r}0.1511 \\
(0.0340)\end{array}$ & $\begin{array}{r}0.1237 \\
(0.0368)\end{array}$ \\
\hline Country Tax Rate & $\begin{array}{r}-0.2075 \\
(0.0457)\end{array}$ & $\begin{array}{r}-0.1598 \\
(0.0435)\end{array}$ & $\begin{array}{r}-0.1959 \\
(0.0470)\end{array}$ & $\begin{array}{l}-0.2173 \\
(0.0970)\end{array}$ & $\begin{array}{r}-0.1341 \\
(0.1051)\end{array}$ \\
\hline IMF Capital Control Dummy & & $\begin{array}{r}0.0050 \\
(0.0109)\end{array}$ & & & \\
\hline Shatz Capital Control Dummy & & & $\begin{array}{r}-0.0472 \\
(0.0202)\end{array}$ & & \\
\hline Post Liberalization Dummy & & & & & $\begin{array}{r}0.0823 \\
(0.0482)\end{array}$ \\
\hline Parent, Industry, and Year Fixed & & & & & \\
\hline Effects? & $\mathrm{Y}$ & $\mathrm{Y}$ & Y & $\mathrm{N}$ & $\mathrm{N}$ \\
\hline GDP and Wage Controls? & $\mathrm{Y}$ & $\mathrm{Y}$ & $\mathrm{Y}$ & $\mathrm{N}$ & $\mathrm{N}$ \\
\hline Affiliate and Year Fixed Effects? & $\mathrm{N}$ & $\mathrm{N}$ & $\mathrm{N}$ & $\mathrm{Y}$ & $\mathrm{Y}$ \\
\hline $\begin{array}{l}\text { No. of Obs. } \\
\text { R-Squared }\end{array}$ & $\begin{array}{r}128,368 \\
0.2286\end{array}$ & $\begin{array}{r}108,942 \\
0.2104\end{array}$ & $\begin{array}{r}108,657 \\
0.2150\end{array}$ & $\begin{array}{c}12,867 \\
0.6502\end{array}$ & $\begin{array}{c}12,867 \\
0.6520\end{array}$ \\
\hline
\end{tabular}

Notes: The dependent variable in each specification is the ratio of net income to owners' equity. The analysis uses analytic weights equal to owners equity to transform the specifications in a way that is equivalent to multiplying through by owners' equity. Country Tax Rate is the median tax rate in an affiliate's host country. The IMF Capital Control Dummy and the Shatz Capital Control Dummy are dummies equal to one if a country imposes capital controls and zero otherwise. Specification (1)-(3) include parent, industry, and year fixed effects and observations for all affiliate years, and as well as three powers of log GDP and the log of the median annual compensation per employee paid by affiliates in a particular country and year. Specifications (4) and (5) include affiliate and year fixed effects and observations from countries that undergo capital control liberalizations. The post liberalization dummy is equal to one in the year of and each of the years following liberalizations. Heteroskedasticity-consistent standard errors that correct for clustering across country/year cells are presented in parentheses. 
Table 5

Capital Controls and Transfer Pricing Activity by U.S. Multinationals, as Measured by Trade Surpluses

Dependent Variable: Parent Trade Surplus

(1)

$-30.3515$

(8.5616)

0.3684

$(0.0630)$

IMF Capital Control Dummy

Shatz Capital Control Dummy

Country Tax Rate

Dummy

Constant

(0.0630)

Shatz Capital Control Dumny

(2)

(3)

$-36.9926$

(8.9050)

$-53.5913$

(16.5557)

0.3793

(0.0757)

(0.0711)

0.0322

(0.0175)

0.0708

(0.0331)

$\mathrm{Y}$
$\mathrm{Y}$

$\mathrm{Y}$

GDP and Wage Controls?

No. of Obs.

R-Squared
24,162

0.2023
$\mathrm{Y}$

Y

20,446

0.2066
19,937

0.2039

The dependent variable in each specification is the difference between parent exports to the affiliate and parent imports from the affiliate divided by the sum of these two values, calculated using data for each industry in each country and year. Country Tax Rate is the median tax rate in an affiliate's host country. The IMF Capital Control Dummy and the Shatz Capital Control Dummy are dummies equal to one if a country imposes capital controls and zero otherwise. Each specification includes industry and year fixed effects as well as three powers of log GDP and the log of the median annual compensation per employee paid by affiliates in a particular country and year. Heteroskedasticity-consistent standard errors that correct for clustering across country/year cells are presented in parentheses. 
Table 6

The Impact of Capital Controls on the Propensity of U.S. Multinationals to Pay Dividends

Dependent Variable: Dummy Equal to
One if Dividend Payment Made

Country Tax Rate

0.9505

(0.0817)

IMF Capital Control Dummy

Shatz Capital Control Dummy

(1)

Full Sample

$(0.0817)$

(2)

(2)

1.1526

0.0890

(0.0196)

Post Liberalization Dummy

Return on Assets

4.5648

4.5676

(0.0676)

4.6543

(0.0686)

(3)
1.0245
$(0.0940)$

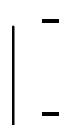

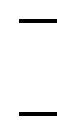

Liberalizing Countries

$(0.0641)$

$\begin{array}{ll} & \\ \mathrm{Y} & \mathrm{Y} \\ \mathrm{Y} & \mathrm{Y} \\ \mathrm{N} & \mathrm{N}\end{array}$

Parent/Year Fixed Effects?

GDP and Wage Controls?

Affiliate and Year Fixed Effects?

No. of Obs.

Log Likelihood

97,061

$-43,235$
0.3589

(0.0323)

(4)

(5)

2.2556

2.5956

(0.3990)

(0.4089)
$-0.5701$

(0.1483)

3.9830

(0.2431)

4.0272

(0.2441)

$\mathrm{N}$

$\mathrm{N}$

Y

7,556

$-2,854$
85,985

$-38,022$

Notes: The dependent variable in each specification is a dummy that is equal to one if an affiliate makes a dividend payment in a particular year and zero if it does not. Country Tax Rate is the median tax rate in an affiliate's host country. The IMF Capital Control Dummy and the Shatz Capital Control Dummy are dummies equal to one if a country imposes capital controls and zero otherwise. Return on assets is the ratio of affiliate net income to assets. Specification (1)-(3) include Parent/Year fixed effects and observations for all affiliate years, and as well as three powers of log GDP and the log of the median annual compensation per employee paid by affiliates in a particular country and year. Specifications (4) and (5) include affiliate and year fixed effects and observations from countries that undergo capital control liberalizations. The post liberalization dummy is equal to one in the year of and each of the years following liberalizations. Standard errors are presented in parenthesess. 
Table 7

The Impact of Capital Controls on the Dividend Policy of U.S. Multinationals

\begin{tabular}{|c|c|c|c|c|c|c|c|c|c|c|}
\hline \multirow[t]{2}{*}{ Dependent Variable: Dividend Paid } & \multicolumn{6}{|c|}{ Full Sample } & \multicolumn{4}{|c|}{ Liberalizing Countries } \\
\hline & (1) & $(2)$ & (3) & (4) & (5) & (6) & (7) & $(8)$ & (9) & $(10)$ \\
\hline Constant & $\begin{array}{l}364.5 \\
(94.1)\end{array}$ & $\begin{array}{l}1337.3 \\
(146.2)\end{array}$ & $\begin{array}{l}417.8 \\
(74.6)\end{array}$ & $\begin{array}{l}1371.2 \\
(122.2)\end{array}$ & $\begin{array}{l}429.9 \\
(94.0)\end{array}$ & $\begin{array}{l}1842.8 \\
(171.3)\end{array}$ & $\begin{array}{r}747.8 \\
(196.8)\end{array}$ & $\begin{array}{r}1743.8 \\
(250.4)\end{array}$ & $\begin{array}{r}562.0 \\
(172.1)\end{array}$ & $\begin{array}{l}1502.6 \\
(289.1)\end{array}$ \\
\hline Net Income & $\begin{array}{r}0.4122 \\
(0.0209)\end{array}$ & $\begin{array}{r}0.3567 \\
(0.0233)\end{array}$ & $\begin{array}{r}0.3969 \\
(0.0215)\end{array}$ & $\begin{array}{r}0.3385 \\
(0.0250)\end{array}$ & $\begin{array}{r}0.4244 \\
(0.0232)\end{array}$ & $\begin{array}{r}0.3174 \\
(0.0259)\end{array}$ & $\begin{array}{r}0.2980 \\
(0.0471)\end{array}$ & $\begin{array}{r}0.2023 \\
(0.0369)\end{array}$ & $\begin{array}{r}0.2615 \\
(0.0442)\end{array}$ & $\begin{array}{r}0.1446 \\
(0.0589)\end{array}$ \\
\hline Lagged Dividends & $\begin{array}{r}0.2588 \\
(0.0277)\end{array}$ & $\begin{array}{r}0.0822 \\
(0.0240)\end{array}$ & $\begin{array}{r}0.2382 \\
(0.0325)\end{array}$ & $\begin{array}{r}0.0280 \\
(0.0311)\end{array}$ & $\begin{array}{r}0.2141 \\
(0.0307)\end{array}$ & $\begin{array}{r}0.0047 \\
(0.0268)\end{array}$ & $\begin{array}{r}0.2590 \\
(0.0898)\end{array}$ & $\begin{array}{r}0.1195 \\
(0.0569)\end{array}$ & $\begin{array}{r}0.5133 \\
(0.0795)\end{array}$ & $\begin{array}{r}0.3449 \\
(0.0892)\end{array}$ \\
\hline $\begin{array}{l}\text { IMF Capital Control Dummy } \\
\text { Interacted with Net Income }\end{array}$ & & & $\begin{array}{r}-0.0222 \\
(0.0420)\end{array}$ & $\begin{array}{r}-0.0545 \\
(0.0421)\end{array}$ & & & & & & \\
\hline $\begin{array}{l}\text { IMF Capital Control Dummy } \\
\text { Interacted with Lagged Dividends }\end{array}$ & & & $\begin{array}{r}0.0621 \\
(0.0800)\end{array}$ & $\begin{array}{r}0.1118 \\
(0.0582)\end{array}$ & & & & & & \\
\hline $\begin{array}{l}\text { Shatz Capital Control Dummy } \\
\text { Interacted with Net Income }\end{array}$ & & & & & $\begin{array}{r}-0.1228 \\
(0.0544)\end{array}$ & $\begin{array}{r}-0.1216 \\
(0.0679)\end{array}$ & & & & \\
\hline $\begin{array}{l}\text { Shatz Capital Control Dummy } \\
\text { Interacted with Lagged Dividend }\end{array}$ & & & & & $\begin{array}{r}0.3247 \\
(0.0735)\end{array}$ & $\begin{array}{r}0.2799 \\
(0.1403)\end{array}$ & & & & \\
\hline $\begin{array}{l}\text { Post Liberalization Dummy } \\
\text { Interacted with Net Income }\end{array}$ & & & & & & & & & $\begin{array}{r}0.0367 \\
(0.0671)\end{array}$ & $\begin{array}{r}0.0851 \\
(0.0620)\end{array}$ \\
\hline $\begin{array}{l}\text { Post Liberalization Dummy } \\
\text { Interacted with Lagged Dividend }\end{array}$ & & & & & & & & & $\begin{array}{r}-0.3186 \\
(0.1072)\end{array}$ & $\begin{array}{r}-0.2664 \\
(0.0908)\end{array}$ \\
\hline Parent Fixed Effects? & $\mathrm{Y}$ & $\mathrm{N}$ & $\mathrm{Y}$ & $\mathrm{N}$ & $\mathrm{Y}$ & $\mathrm{N}$ & $\mathrm{Y}$ & $\mathrm{N}$ & $\mathrm{Y}$ & $\mathrm{N}$ \\
\hline Affiliate Fixed Effects? & $\mathrm{N}$ & $\mathrm{Y}$ & $\mathrm{N}$ & $\mathrm{Y}$ & $\mathrm{N}$ & $\mathrm{Y}$ & $\mathrm{N}$ & $\mathrm{Y}$ & $\mathrm{N}$ & $\mathrm{Y}$ \\
\hline No. of Obs. & 87,339 & 87,339 & 74,482 & 74,482 & 56,689 & 56,689 & 8,552 & 8,552 & 8,552 & 8,552 \\
\hline R-Squared & 0.3836 & 0.5157 & 0.3702 & 0.5005 & 0.3735 & 0.5430 & 0.4885 & 0.6088 & 0.5159 & 0.6212 \\
\hline \multirow{2}{*}{ Payout ratio } & \multicolumn{2}{|c|}{ Without Controls } & 0.5210 & 0.3483 & 0.5400 & 0.3189 & 0.4022 & 0.2298 & 0.3702 & 0.2492 \\
\hline & \multicolumn{2}{|l|}{ With Controls } & 0.5354 & 0.3302 & 0.6539 & 0.2737 & & & 0.5372 & 0.2207 \\
\hline \multirow{2}{*}{ Adjustment Parameter } & \multicolumn{2}{|c|}{ Without Controls } & 0.7618 & 0.9720 & 0.7859 & 0.9953 & 0.7410 & 0.8805 & 0.8053 & 0.9216 \\
\hline & \multicolumn{2}{|l|}{ With Controls } & 0.6997 & 0.8602 & 0.4612 & 0.7153 & & & 0.4867 & 0.6551 \\
\hline
\end{tabular}

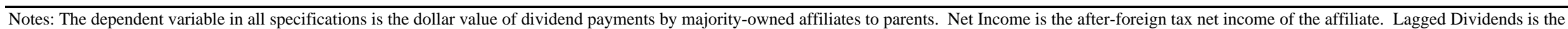

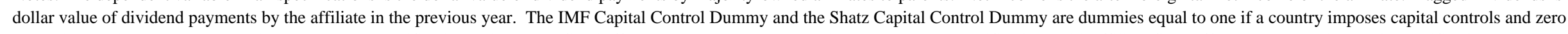

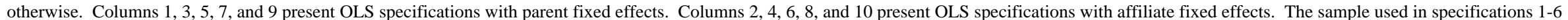
includes all affiliates and the sample in specifications 7-10 includes only affiliates in countries that liberalize their capital controls. Heteroskedasticity-consistent standard errors are presented in parentheses. 
Table 8

The Impact of Capital Controls on Multinational Affiliate Size

\begin{tabular}{|c|c|c|c|c|c|}
\hline \multirow{2}{*}{$\begin{array}{c}\text { Dependent Variable: Log of Affiliate } \\
\text { Assets } \\
\end{array}$} & \multicolumn{3}{|c|}{ First Appearance } & \multicolumn{2}{|c|}{ Liberalizing Countries } \\
\hline & (1) & (2) & (3) & (4) & (5) \\
\hline Constant & $\begin{array}{l}107.7197 \\
(24.2568)\end{array}$ & $\begin{array}{l}106.5692 \\
(25.2007)\end{array}$ & $\begin{array}{r}131.5939 \\
(34.8195)\end{array}$ & $\begin{array}{r}9.6327 \\
(0.0659)\end{array}$ & $\begin{array}{r}9.6018 \\
(0.0710)\end{array}$ \\
\hline Country Tax Rate & $\begin{array}{r}-0.3020 \\
(0.1405)\end{array}$ & $\begin{array}{r}-0.3558 \\
(0.1457)\end{array}$ & $\begin{array}{r}-0.4689 \\
(0.1670)\end{array}$ & $\begin{array}{r}0.3926 \\
(0.2005)\end{array}$ & $\begin{array}{r}0.4896 \\
(0.2189)\end{array}$ \\
\hline IMF Capital Control Dummy & & $\begin{array}{r}-0.1590 \\
(0.0314)\end{array}$ & & & \\
\hline Shatz Capital Control Dummy & & & $\begin{array}{r}-0.1269 \\
(0.0655)\end{array}$ & & \\
\hline Post Liberalization Dummy & & & & & $\begin{array}{r}0.1562 \\
(0.0607)\end{array}$ \\
\hline Parent, Industry, and Year Fixed & & & & & \\
\hline Effects? & $\mathrm{Y}$ & $\mathrm{Y}$ & $\mathrm{Y}$ & $\mathrm{N}$ & $\mathrm{N}$ \\
\hline GNP Controls? & $\mathrm{Y}$ & $\mathrm{Y}$ & $\mathrm{Y}$ & $\mathrm{N}$ & $\mathrm{N}$ \\
\hline Affiliate and Year Fixed Effects? & $\mathrm{N}$ & $\mathrm{N}$ & $\mathrm{N}$ & $\mathrm{Y}$ & $\mathrm{Y}$ \\
\hline No. of Obs. & 22,015 & 18,623 & 18,507 & 17,810 & 17,810 \\
\hline R-Squared & 0.4959 & 0.4819 & 0.4847 & 0.8700 & 0.8703 \\
\hline
\end{tabular}

Notes: The dependent variable in each specification is the log of affiliate assets. Country Tax Rate is the median tax rate in an affiliate's host country. The IMF Capital Control Dummy and the Shatz Capital Control Dummy are dummies equal to one if a country imposes capital controls and zero otherwise. Specification (1)-(3) include parent, industry, and year fixed effects and observations for the first appearce of all affiliates subsequent to 1982, as well as three powers of log GDP and the log of the median annual compensation per employee paid by affiliates in a particular country and year. Specifications (4) and (5) include affiliate and year fixed effects and observations from countries that undergo capital control liberalizations. The post liberalization dummy is equal to one in the year of and each of the years following liberalizations. Heteroskedasticity-consistent standard errors that correct for clustering across country/year cells are presented in parentheses. 
Table 9

The Impact of Capital Controls on the Retained Earnings of Multinational Affiliates

Dependent Variable: Retained Earnings/Total Assets

(1)

\section{Constant}

Country Tax Rate

Shatz Capital Control Dummy
IMF Capital Control Dummy

(2)

(3)

$$
\begin{array}{rr}
10.4160 & 8.8870 \\
(8.4270) & (8.0428) \\
-0.0926 & -0.0376 \\
(0.0676) & (0.0593) \\
& -0.0626 \\
& (0.0165)
\end{array}
$$

Parent, Industry, and Year Fixed Effects?

GDP and Wage Controls?

Y

$\mathrm{Y}$

52,388

0.2128
$-0.0661$

(0.0184)

2.9613

(13.2301)

$-0.1310$

$\mathrm{Y}$

$\mathrm{Y}$

49,695

0.2170

\section{R-Squared}

0.2160

\author{
0.2128
}

Notes: The dependent variable in each specification is the ratio of retained earnings to assets. Country Tax Rate is the median tax rate in an affiliate's host country. The IMF Capital Control Dummy and the Shatz Capital Control Dummy are dummies equal to one if a country imposes capital controls and zero otherwise. All specification include parent, industry, and year fixed effects and observations for all benchmark years, as well as three powers of log GDP and the log of the median annual compensation per employee paid by affiliates in a particular country and year. Heteroskedasticityconsistent standard errors that correct for clustering across country/year cells are presented in parentheses. 